Volume 1, No. 3, September - December 2016 ISSN: 2503-4235 (p); 2503-4243 (e)

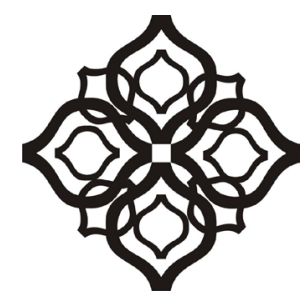

Shirkah

Journal of Economics and Business 


\section{Shirkah}

\section{Journal of Economics and Business \\ Vol. 1, No. 3, September-December 2016 \\ ISSN: 2503-4235 (p); 2503-4243 (e)}

\section{Editor in Chief}

Sri Walyoto

\section{Editorial Boards}

Abu Umar Faruq Ahmad, UBD School of Business and Economics, Brunei Darussalam

Amelia Fauzia, Asia Research Institute, National University of Singapore, Singapore

Cedomir Nestorovic, ESSEC Business School Asia Pacific, Singapore

Dwi Condro Triono, Faculty of Islamic Economics and Business, IAIN Surakarta, Indonesia

Fahmy Radhi, Faculty of Economics and Business Universitas Gadjah Mada, Yogyakarta, Indonesia

Hasan Basri, Syiah Kuala University, Aceh, Indonesia

Jaka Sriyana, Faculty of Economics, Universitas Islam Indonesia, Yogyakarta, Indonesia

Johan Fischer, Department of Social Sciences and Business Roskilde University, Denmark

Masudul Alam Choudhury, Postgraduate Program in Islamic Economics and Finance, Trisakti University, Jakarta, Indonesia and the College of Economics and Political Science (CEPS) in Sultan Qaboos University (SQU), Oman

M. Falik Isbah, School of Humanities and Social Science, University of New South Wales, Australia

M. Ishaq Bhatti, La Trobe Business School Department of Economics and Finance La Trobe University, Australia

Nunung Nurul Hidayah, Aston Business School, Aston University, Birmingham, United Kingdom

Najib Kailani, Pascasarjana, Universitas Islam Negeri (UIN) Sunan Kalijaga, Yogyakarta, Indonesia

Shaikh M Ghazanfar, Departement of Economics, University of Idaho, Russian Federation 
Managing Editors

M. Endy Saputro

M. Zainal Anwar

\section{Assistant to Editor}

Supriyanto

Shirkah Journal of Economics and Business is a peer-reviewed journal published three times a year (January-April, May-August and September-December) by Faculty of Islamic Economics and Business, Institut Agama Islam Negeri (IAIN/ State Institute for Islamic Studies) Surakarta Central Java, Indonesia. The main objective of Shirkah is to offer an academic space of exchange ideas and initiate the increase number of qualified article produced by postgraduate students, practitioners and academicians.

\section{Editorial Office}

Ruang Jurnal Shirkah

Lantai Dasar, Sayap Barat, Fakultas Ekonomi dan Bisnis Islam, IAIN Surakarta

Jln. Pandawa No. 1, Kartasura, Sukoharjo, Jawa Tengah Kode Pos. 57168

Phone (+62271) 781516 Fax: (+62271)782336

E-mail: shirkahiainsurakarta@gmail.com

Website: http://shirkah.or.id/ 



\section{Shirkah}

\section{Journal of Economics and Business}

Vol. 1, No. 3, September-December 2016

ISSN: 2503-4235 (p); 2503-4243 (e)

\section{Table of Contents}

\section{Articles}

Muhfiatun

The Effect of Sharia Monetary Policy and Financing Quality on Financial Performance in Sharia Banking

Roro Hindun

Izzul Fatchu Reza

Understanding Indonesian People Borrowing Money

from Banks and Non-Banking Institutions

M. Nur Rianto Al Arif

299

Monopoly and Ikhtikar in Islamic Economics

Trimulato

Sharia Bank Product Development through Mudhrabah Investment

Aida Nurul Hadiah

Financial Services Authority (OJK) Policy on Debt Proportion and Its Impact on the Profitability of DES Listed Companies in Indonesia

Statement of Financial Accounting Standard (PSAK)

No. 109 and Its Implementation in Several Zakat Management

Organizations in Malang, East Java 



\title{
Financial Services Authority (OJK) Policy on Debt Proportion and Its Impact on the Profitability of DES Listed Companies in Indonesia
}

\author{
Aida Nurul Hadiah \\ Islamic Economic Program, \\ Sekolah Pascasarjana, Universitas Gajah Mada
}

\begin{abstract}
The sharia capital market in Indonesia has different principles and criteria from the conventional capital market, and focuses on "ethics and justice". The desired outcomes of capital market transactions should be in accordance with Islamic ethics and norms as managed in sharia. OJK (Otoritas Jasa Keuangan/ Financial Services Authority) is supervisor and manager of financial service activities in the banking sector, the capital market sector, and the IKNB (Industri Keuangan Non-Bank/ Non-Bank Financial Industry) sector. The research object is capital structure, leverage, and profit. They are managed by size, liquidity, growth, and active structure of the listed company at sharia stock. The research population is 24 companies excluded from the OJK due to a lack of criteria in their 2013-2015 quarterly financial reports. The data analyses used are descriptive statistics and inferential statistics. This analysis finds the effect of the independent variable, dependent variable and control variable simultaneously and partially. The research result shows that capital structure and leverage do not have significant effect.
\end{abstract}

Keywords: OJK (Otoritas Jasa Keuangan), debt proportion, DES

The sharia capital market, as clearly seen on OJK website, launched on March $14^{\text {th }} 2003$ by the Finance Minister, Boediono, accompanied by the chief of BAPEPAM (Capital Market Supervisor Office), Herwidayatno, a MUI (Majelis Ulama Indonesia/Indonesian Council of Ulama) representative, an SRO Management representative, and organization's administrator of social fund profession operator at Indonesia capital 
market. According to Law No. 8 1995, capital market activities are all activities related to general offers and effects trades, public company relate to the published effect, and also the institution and profession relate to effect. The sharia capital market is the financial trade instrument based on sharia. The sharia capital market needs proper criteria due to its significant and rapid development and high level of public interest.

The sharia capital market has different principles and criteria to conventional capital market and emphasizes "ethics and justice." The goal is that all capital market transactions be in accordance with Islamic ethics, managed in sharia (Muhammad, 2014). The capital market description is efficient, ethical, and fair. Quoting Shefrin and Statman, Muhammad (2014) states that the capital market has six characteristics: (1) no coercion, (2) no interpretation element, (3) the right to get similar information, (4) the right to process similar information, (5) is free from personal thrill, and (6) the right to transact with efficient price. These activities need an authority to supervise and manage the risk; while OJK is the referred institution. OJK (Financial Services Authority), as declared in its website, is an institution established to manage and supervise the financial service activities in the banking sector, the capital market sector, and the IKNB sector. OJK establishes regulations to manage the sharia capital market following the BAPEPAM's criteria and sharia stock publishing. It will, more or less, affect the issuer (emiten) who creates the sharia stock. The greatest effect for the issuer is profitability.

The regulation affecting the exclusion of the 24 companies is due to the company's debt proportion being at the standard limit. According to $\mathrm{OJK}$, the debt proportion limit for sharia stock producing companies is $10 \%$. The regulation is stricter than before with maximum company debt proportion of $45 \%$. OJK considers high debt proportion will increase public risk. This is contrary to sharia economic principles in terms of 
personal thrill. The emitten who is producing stock should provide security and trust to the public.

Profitability is described by Riyanto (2011) as a company's ability to gain profit from its ability and available sources, such as selling, cash, capital, staff, branches, and others. These recent studies show how capital effect on profitability. Yuliati (2013) has said that working capital simultaneously has significant effect on profitability. This differs from the findings of Danuletio (2010) and Mathuva (2010) which suggest that debt structure has significant negative effect on profitability. This is supported by Nugrahara's (2009) finding that working capital financing variable has a negative significant correlation on profitability. As Chhaochharia and Grinstein (2007) state, the Sarbanes-Oxley law and several changes in the USA stock exchange regulations affect a company's value.

The result shows that there is the existence of a gap in the research in relation to the profitability effect of the debt proportion policy stated by the OJK for the sharia stock listed companies. OJK's policy affects company profitability, and one of the researcher's aims was to find out the differences on company profitability before and the after the regulation was launched.

\section{Pecking Order Theory}

This theory discusses company financing and prefers funds from a company operation's holding profit (internal financing), however, when internal financing is insufficient external financing (external financing) is needed through initially launching saver securities. It operates with a company publishing bonds and then follows with securities with option characteristics (such as conversion bonds). While it does not solve the problem, the company should publish new stocks (Husnan, 2004). Therefore, there will not be a debt to equity ratio target; due to the use 
of internal and external financing types. Companies generally prefer to finance using internal capital, such as financing from cash flow, holding profits, and depreciation cost.

Kahle and Shastri (2004) developed pecking order theory which states that a company should perform three stages in financing: first, financing from retained earnings; second, from debt; and third, from equity. These stages enable profitable companies to have lower capital structure than less profitable companies due to the profitable company's ability to finance its investment with retained earnings. The theory highlights that profitability has a negative effect on capital structure (Muhammad, 2014, p. 552). Riyanto (2005) suggest a company's changing nature depends on the term - the short term company will have a pecking order nature and long term company will show a trade-off framework. The first hypothesis (H1) capital structure has a positive significant effect on profitability.

Leverage is a company determinant to gain debt due its ability to describe capital holders' ability to repay or close the debt from debt providers. Leverage also means activa or finance use with the company paying permanent costs or permanent burden (Riyanto, 2008). Leverage has various ratios; one of them is Total Debt to Equity Ratio. The ratio is a measurement of the company's ability to pay its long term debt. The description is:

Total debt to equity ratio $=$

$$
\frac{(\text { short }- \text { term debt }+ \text { long }- \text { term debt })}{\text { individual capital }}
$$

The conclusion based on the statement above is total debt to capital ratio is not only able to be used by a company to fund activa (assets), capital, and bear the permanent burden, but also can be used to increase the income. Thus, the second hypothesis (H2): leverage has a significant negative effect on profitability. 
Profitability is the reflection of company performance. A company's profitability is the result of its production and achievement. It has various measurements; one of them is ROE (Return on Equity) which is gained from comparison of net profit (EAT) with total equity (Sudana, 2011).

$$
\mathrm{ROE}=\frac{E A T}{\text { total equity }}
$$

The ROE function is a company measurement device to gain profit for stock holders. ROE is used as an IDX listed company profitability level measurement in this research. This is due to its ability to measure a company's ability to gain profit for stock holders in the form of capital equity invested by stock holders. The ratio describes a company's management affectivity level. Therefore, it will become the central focus for investors as long term investors are highly concerned with profitability analysis, for example, stock holders will observe actual profits. The third hypothesis $(\mathrm{H} 3)$ there are changes before and after exclusion from DES.

\section{Activity Yields Profit}

The research object is capital structure, leverage and profit, controlled by size of liquidity, growth, and activa structure of the sharia stock listed companies. The research population is 24 companies excluded by OJK due to their not fulfilling the required criteria in their quarterly 2013-2015 financial reports. This research is descriptive qualitative and comparative research. The research purpose is to describe and summarize information on the effect of capital structure, leverage on profitability, and profitability difference before and after implementation of the OJK policy.

The dependent variable in this research is profitability level as it reflects a company's activities; while the independent variables here are modal structure and leverage. The control variables are size, liquidity, growth, 
and activa structure. The purpose of these variables is to avoid the effects of foreign factors on dependent and independent variables (Sugiyono, 2012). These variables are assumed to have an effect on profitability. The steps of research data analysis are: (1) descriptive statistics based on the collected data from samples and then describing the population characteristics (Boediono, 2001); (2) inferential statistics with multiple linear regression model with contribution from SPSS (Statistic Package Linier Regression Model) version 20.00 for Windows. The function of this analysis is to find the effect among dependent, independent, and control variables simultaneously and partially. The formula for this model is:

Profitability $=\alpha+b_{1}$ capital structure $+b_{2}$ leverage $+b_{3}$ size $+b_{4}$ liquidity + $\mathrm{b}_{5}$ activa structure $+\mathrm{e}$

It also used t-test, 2 correlated samples, and paired t-test (beforeafter). The next formula will solve the $\mathrm{H}_{3}$ problem on whether there were differences before and after the introduction of the OJK policy. The formula is:

$$
t=\frac{\sum D}{\sqrt{\frac{n \cdot \sum D^{2}-\left(\sum D\right)^{2}}{n-1}}}
$$

Explanation:

$\mathrm{D}=$ Score Difference of group 1 and group 2

$\mathrm{n}=$ Sample size 
Table 1: Multiple Linear Regression Model Result

\begin{tabular}{lccc}
\hline \multicolumn{1}{c}{ Variable } & Regression Coefficient & Tolerance & VIF \\
\hline Constant & 28.749 & & \\
Capital Structure & .002 & .110 & 9.126 \\
Liquidity & -.003 & .997 & 1.003 \\
Activa Structure & -.336 & .982 & 1.018 \\
Size & -.994 & .979 & 1.022 \\
Leverage & -.001 & .110 & 9.125 \\
\hline R Square & .207 & & \\
F & 10.512 & & \\
DW & .955 & &
\end{tabular}

Classical Assumption Test. Table 1 shows DW value is 0.955 . This value is located between -2 and +2 or $-2 \leq \mathrm{DW} \leq+2$ meaning the Multiple Linear Regression Model has no correlation. Picture 1 shows spots spread above and below the $\mathrm{Y}$ axis that do not have a regular pattern. This means the independent variable does not show homoscedasticity or heteroscedasticity. Multicollinearity test is performed observing tolerance value and VIF (table 1). Tolerance value limit is above 5\% with VIF value less than 10, meaning there is no multicollinearity in this model. Picture 2 shows a normal curve line, meaning the data studied above was distributed normally. The normal probability plots are also normally distributed due to the line (dots) which is diagonal. 
Picture 1

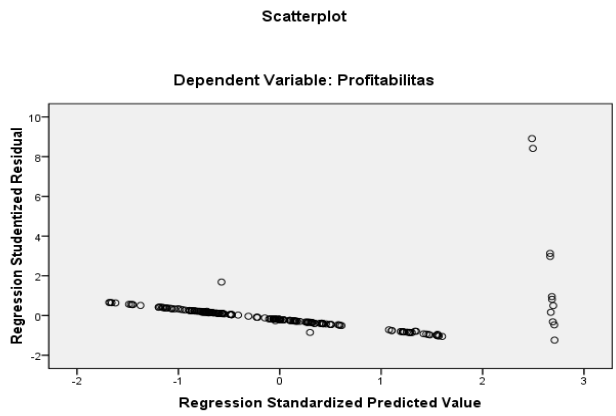

Picture 2

Normal P.P Plot of Regression Standardized Residual

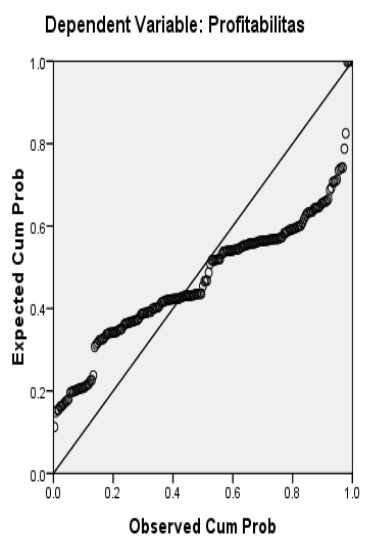

Hypothesis Test. The Multiple Linear Regression Model test (table) result and then the result returned to its previous condition are shown below:

Profitability $=28.749+0.002$ capital structure -0.003 liquidity -0.336 activa structure -0.994 size -0.001 leverage $+\mathrm{e}$ 
Table 1 shows the determination coefficient ( $\mathrm{R}$ square) with value 0.207 . This means the capital structure variable's contribution, liquidity, activa structure, size, and leverage of listed company's profitability is $20.7 \%$. The rest are affected by other variables not studied in this research.

Table 2: ANOVA ${ }^{\mathrm{b}}$

\begin{tabular}{|ll|r|r|}
\hline Model & F & Sig. \\
\hline 1 & $\begin{array}{l}\text { Regression } \\
\text { Residual } \\
\text { Total }\end{array}$ & 10.512 & $.000^{\mathrm{a}}$ \\
\hline
\end{tabular}

a. Predictors: (Constant), Leverage, Liquidity, Activa Structure, Size, Capital Structure

b. Dependent Variable: Profitability

F value 10.512 with significant level below 0.05 . It shows the model is fit, meaning capital structure, liquidity; activa structure, size, and leverage affect the profitability.

Table. 3: Coefficients ${ }^{\mathrm{a}}$

\begin{tabular}{|ll|r|}
\hline \multicolumn{2}{|l|}{ Model } & Sig. \\
\hline $1 \quad$ (Constant) & .000 \\
& Modal Structure & .753 \\
& Liquidity & .562 \\
Activa Structure & .515 \\
Size & .000 \\
Leverage & .665 \\
\hline
\end{tabular}

Table 3 shows sig value. The capital structure is 0.753 , Meaning capital structure does not have a significant effect. Liquidity as control variable gains 0.562 sig value. It shows liquidity does not have significant effect. Activa structure as control variable also does not have significant effect on profitability. However, size as control variable has significant effect on 
profitability.

$$
\begin{gathered}
t=\frac{-40,1172006}{\sqrt{\frac{370,4995342-6,333814064}{23}}} \\
t=-10.08196086
\end{gathered}
$$

The value gained from t-test calculation is $-10.08196086>\mathrm{t}$-table, meaning there is difference in profit before and after the OJK policy on debt proportion is launched.

The research result shows activa structure does not have significant positive effect; however, the leverage has significant negative effect. It shows there is no effect on profitability (ROE) gained by the company. However, there is difference in profitability of the company before and after the OJK policy on debt proportion which meant the companies were excluded from the DES list.

\section{Conclusion}

Investor candidates who want to invest in DES listed companies should focus on the company's debt proportion limit and size. This research used tri-monthly financial reports. It is suggested that future research use annually audited financial reports and add more variables such as SalesPrice, Price Book Value, and Growth. The research conclusion shows the variables of capital structure, liquidity, activa structure, size, and leverage have simultaneous effect on stock return which affect the profitability of companies listed with the DES. Partially, only one variable, size as control variable, has significant effect. Capital structure and leverage do not have significant effect on profitability. The difference in profitability before and after the OJK policy on debt proportion, resulted in the companies above being excluded from the DES list. 


\section{References}

Boediono, W. K. (2001). Teori dan Aplikasi Statistika dan Probabilitas. Bandung: Remaja Rosdakarya.

Chhaochharia, V., \& Grinstein, Y. (2007). Corporate Governance and Firm Value: The Impact of the 2002 Governance Rules. The Journal of Finance, 62(4), 1789-1825.

Danuletiu, A. E. (2010). Working Capital Management and Profitability: a Case of Alba Country Companies. Annales Universitatis Apulensis: Series Oeconomica, 12(1), 364.

Gaud, P., Hoesli, M., \& Bender, A. (2007). Debt-equity Choice in Europe. International Review of Financial Analysis, 16(3), 201-222.

Husnan, S. (2004). Dasar-Dasar Teori Portofolio dan Analisis Investasi. Yogyakarta: Penerbit UPP-AMP YKPN

Kahle, K. M., \& Shastri, K. (2004). Executive Loans. Journal of Financial and Quantitative Analysis, 39(04), 791-811.

Mathuva, D. (2010). The Influence of Working Capital Management Components on Corporate Profitability. Research Journal of Business Management, 4(1), 1-11.

Muhammad. (2014). Manajemen Keuangan Syari'ah. Yogyakarta: UPP STIM-YKPN.

Riyanto, B. (2011). Dasar-dasar Pembelanjaan Perusahaan (Fouth Edition ed.). Yogyakarta: UPP STIM-YKPN.

Sudana, I. (2011). Manajemen Keuangan Perusahaan: Teori dan Praktik. Jakarta: Erlangga.

Sugiyono, M. P. P. K. (2007). Pendekatan Kuantitatif. Bandung: Alfabeta. Yuliati, N. W. (2013). Pengaruh Kebijakan Modal Kerja Terhadap Profitabilitas Pada Perusahaan Hotel dan Restoran di Bursa Efek Indonesia. E-Jurnal Ekonomi dan Bisnis Universitas Udayana, 2(10). 
Website:

www.ojk.go.id 
Vol. 1 No. 3, September - December 2016 